\title{
Implementasi Kewajiban Notaris untuk Melekatkan Sidik Jari Para Penghadap pada Minuta Akta
}

\author{
Rizka Rahmawati \\ Fakultas Hukum Universitas Udayana, Bali, Indonesia \\ E-mail: rizka.rahmawatii@gmail.com
}

\begin{abstract}
The unclear setting regarding the notary's obligation to attach the fingerprints of the viewers influences the implementation of these provisions. There is a vagueness of norms against the provisions of Article 16 paragraph (1) letter c UUJN-P because they are not explained in detail. In addition, there is also a norm conflict in Article 16 paragraph (1) letter c UUJN-P with Article 38 paragraph (4) UUJN-P number 2 concerning attachment of fingerprints. The problem is whether the background of the notary's obligation to attach fingerprints to the receipt of the deed, how is the procedure for carrying out the obligation of the notary in attaching fingerprints to the deed of the deed, and the legal consequences of the deed and notary the fingers of the viewers on the minuta deed based on UUJN-P jo. UUJN. This research will be conducted using a type of normative juridical research with a type of legislative approach (concept approach) and a conceptual approach. The obligation of the notary to attach the fingerprint of the face in the background with the aim of anticipating if at any time the viewers deny their signature to the Minutes of Deed and this is an attitude of caution. In addition, regarding the procedure of implementation, regarding the obligation of the notary to attach fingerprints using the thumb/left thumb stamp and made on a new sheet or additional width. Normatively not attaching fingerprints does not give effect to the position of the certificate, the deed of the Notary is still valid and binding and has the power of proof that is perfect. For a Notary who does not carry out the obligation to attach a fingerprint to the Minute of Deed, the Notary may be subject to administrative sanctions.
\end{abstract}

Keywords: Obligations, Minutes of Deed, Notary, Fingerprint

\section{A. PENDAHULUAN.}

Notaris sebagai pejabat umum memiliki peran sentral dalam penegakan hukum di Indonesia. Notaris dalam melaksanakan jabatannya tentunya memiliki kewajiban yang harus dijalankan. Jabatan notaris merupakan jabatan yang keberadaannya dikehendaki guna mewujudkan hubungan hukum diantara 
subyek-subyek hukum yang bersifat perdata. Notaris sebagai salah satu pejabat umum mempunyai peranan penting yang dipercaya oleh pemerintah dan masyarakat untuk membantu pemerintah dalam melayani masyarakat dalam menjamin kepastian, ketertiban, dan perlindungan hukum melalui akta otentik yang dibuat oleh atau di hadapannya, mengingat akta otentik sebagai alat bukti terkuat dan memiliki nilai yuridis yang esensial dalam setiap hubungan hukum bila terjadi sengketa dalam kehidupan masyarakat.

Dalam suatu perkara perdata atau dari keseluruhan tahap persidangan dalam penyelesaian perkara perdata, pembuktian memegang peranan yang sangat penting. ${ }^{1}$ Apabila terjadi suatu perkara, akta autentik merupakan alat bukti tertulis yang memiliki sifat terkuat dan terpenuh yang dapat membantu dalam penyelesaiaan perkara. $^{2}$ Pada dasarnya alat bukti yang kuat dan sempurna dalam suatu perbuatan hukum merupakan satu sarana guna menjamin serta memberikan rasa aman kepada para pihak. ${ }^{3}$ Notaris sebagai salah satu penegak hukum karena notaris membuat alat bukti tertulis yang mempunyai kekuatan pembuktian. Para ahli hukum berpendapat bahwa akta notaris dapat diterima dalam pengadilan sebagai bukti yang mutlak mengenai isinya, tetapi meskipun demikian dapat diadakan penyangkalan dengan bukti sebaliknya oleh saksi-saksi, yang dapat membuktikan bahwa apa yang diterangkan oleh notaris dalam aktanya adalah benar.

Notaris merupakan pejabat umum yang keberadaannya ditentukan dalam Undang-Undang Nomor 30 Tahun 2004 (Lembaran Negara Republik Indonesia Tahun 2004 Nomor 117, Tambahan

1 Dinaryanti, A. R. (2013). Tinjauan Yuridis Legalisasi Akta Di Bawah Tangan Oleh Notaris. Legal Opinion, 1 (3), h. 4.

2 Sajadi, I., Saptanti, N., \& Supanto, S. (2015). Tanggung Jawab Notaris Terhadap Keabsahan Akta Notaris Yang Dibuatnya Atas
Lembaran Negara Republik Indonesia Nomor 4432 selanjutnya disebut dengan UUJN). Unifikasi hukum di bidang kenotariatan, undang-undang jabatan notaris ini menjadi dasar yang baru bagi pelembagaan di Indonesia. Selama hampir 10 tahun UUJN diberlakukan sebagai satu-satunya undang-undang yang mengatur tentang jabatan notaris, akhirnya pada tahun 2014 diberlakukan revisi terhadap UUJN. Revisi UUJN ini hanya diberlakukan pada sebagian pasal yang penting, yang selanjutnya selanjutnya terjadi perubahan pada tahun 2014 menjadi Undang-Undang Nomor 2 Tahun 2014 Tentang Perubahan Atas UndangUndang Nomor 3 Tahun 2004 Tentang Jabatan Notaris (Lembaran Negara Republik Indonesia Tahun 2014 Nomor 3, Tambahan Lembaran Negara Republik Indonesia Nomor 5491, selanjutnya disebut dengan UUJN-P). Berdasarkan Pasal 1 angka 1 UUJN-P menentukan pengertian notaris yaitu, "Notaris adalah pejabat umum yang berwenang untuk membuat akta autentik dan memiliki kewenangan lainnya sebagaimana dimaksud dalam Undang-Undang ini atau berdasarkan Undang-Undang lainnya."

Munculnya lembaga notaris dilandasi kebutuhan akan suatu alat bukti yang mengikat selain alat bukti saksi. Adanya alat bukti lain yang mengikat, mengingat alat bukti saksi kurang memadai lagi sebab sesuai dengan perkembangan masyarakat, perjanjianperjanjian yang dilaksanakan anggota masyarakat semakin rumit dan kompleks. Notaris diberi wewenang selaku pejabat Negara atau pejabat umum berdasarkan ketentuan-ketentuan dalam UUJN untuk menjalankan sebagian fungsi publik dari negara, di bidang hukum perdata khususnya di bidang hukum pembuktian.

Penghadap Yang Tidak Dapat Membaca dan Menulis. Repertorium, 2 (2), h. 178.

3 Sukisno, D. (2008). Pengambilan Foto

Copi Minuta Akta dan Pemanggilan Notaris. Mimbar Hukum-Fakultas Hukum Universitas Gadjah Mada, 20 (1), h. 1. 
Akta autentik berdasarkan Pasal 1868 KUHPerdata adalah "suatu akta yang dibuat dalam bentuk yang ditentukan oleh undang-undang, dibuat oleh atau dihadapan pegawai-pegawai umum yang berkuasa untuk itu ditempat dimana akta dibuatnya." Berdasarkan Pasal 1 angka (7) UUJN-P bahwa, "Akta notaris adalah akta autentik yang dibuat oleh atau di hadapan Notaris menurut bentuk dan tata cara yang ditetapkan dalam Undang-Undang ini."

Akta autentik menjadi bukti dari setiap sahnya perjanjian maupun tindakan hukum yang tercantum di dalamnya menjadikan produk hukum notaris tersebut harus mengikuti tata cara pembuatannya sebagaimana telah diatur dalam peraturan perundang-undangan yang artinya apa yang tercantum dalam akta tersebut harus dianggap benar adanya, sampai ada pihak yaitu biasanya pihak lawan harus dapat membuktikan bahwa apa yang tercantum dalam akta tersebut tidak benar. Akta otentik sebagai alat bukti terkuat dan penuh mempunyai peranan penting dalam setiap hubungan hukum dalam kehidupan masyarakat, Melalui akta otentik yang menentukan secara jelas hak dan kewajiban, menjamin kepastian hukum, dan sekaligus diharapkan pula dapat dihindari terjadinya sengketa. ${ }^{4}$

Pada saat menjalankan tugas dan jabatannya, Notaris berkewajiban menyimpan atau merahasiakan segala keterangan atau ucapan yang diberikan dihadapannya sehubungan dengan pembuatan akta. Menjaga kerahasiaan itu merupakan salah satu bentuk kewajiban Notaris sebagaimana ditetapkan oleh UUJN. Di dalam menjalankan tugas dan jabatannya, Notaris juga wajib: "bertindak jujur, saksama, mandiri, tidak berpihak, dan menjaga kepentingan pihak yang terkait dalam perbuatan hukum".

Bahwa pasca UUJN-P diberlakukan terdapat ketentuan terbaru mengenai kewajiban Notaris, yaitu Pasal 16 ayat (1) huruf c UUJN-P, maka Notaris

4 Supriadi. (2006). Etika dan Tanggung Jawab Profesi Hukum di Indonesia. Jakarta: Sinar berkewajiban: "melekatkan surat dan dokumen serta sidik jari penghadap pada Minuta Akta". Jika kita analisa bahwa pengertian minuta akta dalam Pasal 1 angka 8 UUJN-P yaitu, "Minuta Akta adalah asli akta yang mencantumkan tanda tangan para penghadap, saksi, dan Notaris, yang disimpan sebagai bagian dari Protokol Notaris". Bahwa berdasarkan pasal tersebut hanya menentukan hal yang harus dicantumkan dalam minuta kata adalah tanda tangan pengahadap, saksi, dan notaris dan tidak penambahan mengenai kewajiban untuk melekatkan sidik jari. Kemudian dalam Pasal 38 ayat (4) angka 2 UUJN-P mengenai akhir dan penutup akta bahwa "uraian penandatanganan dan tempat penandatanganan atau penerjemahan akta apabila ada". Dalam pasal ini pun tidak menentukan mengenai sidik jari para penghadap.

Berdasarkan uraian diatas terdapat ketidakjelasan mengenai kewajiban notaris dalam melakatkan sidik jari penghadap. Karena dalam hal ini terjadi kekaburan norma terhadap Pasal 16 ayat (1) huruf c hal ini pun menjadi pertanyaan sidik jari penghadap yang mana yang akan dilekatkan karena dalam hal ini dalam penjelasan UUJN-P tidak dijelaskan secara detail. Selain itu juga terjadi konflik norma dalam pasal yang ditentukan UUJN-P yaitu Pasal 16 ayat (1) huruf c tentang kewajiban melekatkan sidik jari pengahadap dan dalam Pasal 1 angka 8 tentang kewajiban yang harus dicantumkan dalam minuta akta hanya tanda tangan penghadap, saksi, dan notaris tidak ditentukan mengenai sidik jari. Begitupun juga dalam Pasal 38 ayat (4) angka 2 yang tidak memuat adanya sidik jari penghadap. Ketidakjelasan pengaturan mengenai kewajiban notaris dalam melekatkan sidik jari para penghadap berpengaruh terhadap pelaksanaan ketentuan tersebut, karena disatu sisi bahwa hal tersebut merupakan

Grafika, h. 29. 
kewajiban notaris yang harus dilaksanakan.

Berdasarkan uraian tersebut di atas, maka terdapat beberapa hal yang menarik untuk dibahas yakni mengenai apakah yang melatarbelakangi terhadap kewajiban notaris untuk melekatkan sidik jari pada penghadap pada minuta akta, bagaimanakah prosedur pelaksanaan kewajiban notaris dalam melekatkan sidik jari para penghadap pada minuta akta, dan mengenai akibat hokum terhadap kedudukan akta dan notaris yang tidak melakukan pembubuhan sidik jari tangan para penghadap pada minuta akta berdasarkan UUJN-P jo. UUJN. Sesuai dengan uraian tersebut maka penulis tertarik untuk melakukan penulisan dengan judul, "Implementasi Kewajiban Notaris untuk Melekatkan Sidik Jari Para Penghadap Pada Minuta Akta".

\section{B. METODE PENELITIAN}

Penelitian ini akan dilakukan menggunakan jenis penelitian yuridis normatif, yang artinya penelitian yang dilakukan dengan meneliti bahan kepustakaan yang ada seperti peraturan perundang-undangan, buku-buku yang berkaitan, serta kamus atau ensiklopedi. ${ }^{5}$ Pendekatan ini dilakukan dengan maksud agar peneliti mendapatkan informasi dari berbagai aspek mengenai isu yang sedang dicoba untuk dicari jawabannya. ${ }^{6}$ Dari beberapa pendekatan yang ada, dalam penelitian ini jenis pendekatan yang akan digunakan adalah pendekatan perundangundangan (statue approach) dan pendekatan konseptual (conceptual approach). Dalam melakukan penelitian ini menggunakan 3 (tiga) sumber bahan hukum yaitu, bahan hukum primer, bahan hukum sekunder, dan bahan hukum tersier. Sumber bahan hukum primer merupakan bahan hukum yang sifatnya mengikat

5 Soekanto, S. \& Mamudji. S. (2009). Penelitian Hukum Normatif Suatu Tinjauan Singkat. Jakarta: RajaGrafindo Persada, h. 13-14. seperti peraturan perundang-undangan. Adapun sumber bahan hukum primer pada penelitian ini meliputi: Kitab UndangUndang Hukum Perdata; Undang-Undang Nomor 30 Tahun 2004 (Lembaran Negara Republik Indonesia Tahun 2004 Nomor 117, Tambahan Lembaran Negara Republik Indonesia Nomor 4432); dan Undang-Undang Nomor 2 Tahun 2014 Tentang Perubahan Atas Undang-Undang Nomor 3 Tahun 2004 Tentang Jabatan Notaris (Lembaran Negara Republik Indonesia Tahun 2014 Nomor 3, Tambahan Lembaran Negara Republik Indonesia Nomor 5491). Sedangkan bahan hukum sekunder merupakan bahan hukum pendukung dari bahan hukum primer seperti, buku-buku, hasil karya ilmiah, artikel internet maupun pendapat para ahli yang berakitan dengan implementasi kewajiban notaris untuk melekatkan sidik jari para penghadap pada minuta akta. Serta bahan hukum tersier yang merupakan bahan yang dapat memberikan petunjuk dan/atau penjelasan mengenai bahan hukum primer dan juga bahan hukum sekunder seperti, kamus hukum dan juga ensiklopedia. Adapun teknik pengumpulan bahan hukum yang digunakan dalam penelitian ini dengan melakukan pencatatan secara sistematis dari bahan-bahan yang mendukung mengenai implementasi kewajiban notaris untuk melekatkan sidik jari para penghadap pada minuta akta yang diperoleh melalui studi kepustakaan. Adapun teknik analisis bahan hukum yang digunakan adalah deskripsi, sistematisasi, interprestasi, dan argumentasi.

\section{PEMBAHASAN}

\section{Latar Belakang Dilakukannya Kewajiban Notaris untuk Melekatkan Sidik Jari Para Penghadap pada Minuta Akta.}

${ }^{6}$ Marzuki, P.M. (2013). Penelitian Hukum. Jakarta: Kencana Prenada Media Group, h. 133. 
Munculnya lembaga notaris dilandasi kebutuhan akan suatu alat bukti yang mengikat selain alat bukti saksi. Adanya alat bukti lain yang mengikat, mengingat alat bukti saksi kurang memadai lagi sebab sesuai dengan perkembangan masyarakat, perjanjianperjanjian yang dilaksanakan anggota masyarakat semakin rumit dan kompleks. Notaris sebagai pejabat publik, dalam pengertian mempunyai wewenang dengan pengecualian, dengan mengkategorikan notaris sebagai pejabat publik, dalam hal ini publik yang bermakna hukum. Notaris sebagai pejabat publik tidak berarti sama dengan pejabat publik dalam bidang pemerintahan yang dikategorikan sebagai badan atau pejabat tata usaha negara, hal ini dapat dibedakan dari produk masingmasing pejabat publik tersebut. Notaris sebagai pejabat publik produk akhirnya yaitu akta otentik, yang terikat dalam ketentuan hukum perdata terutama dalam hukum pembuktian. Notaris merupakan pengemban profesi luhur yang memiliki 3 (tiga) ciri-ciri pokok. Pertama, bekerja secara bertanggungjawab, kedua menciptakan keadilan, dan ketiga bekerja tanpa pamrih demi kepentingan klien dengan menjunjung tinggi harkat dan martabat sesama anggota profesi dan organisasi profesinya.

Kedudukan seorang notaris sebagai suatu fungsionaris dalam masyarakat sebagai seorang pejabat yang dapat diandalkan oleh masyarakat. Seorang notaris biasanya dianggap sebagai seorang pejabat tempat seseorang dapat memperoleh nasihat yang dapat diandalkan. Segala sesuatu yang ditulis serta ditetapkannya (konstatir) adalah benar, notaris merupakan pembuat dokumen yang kuat dalam suatu proses hukum. ${ }^{7}$ Jabatan Notaris di Indonesia diatur di dalam UUJN sebagai salah satu produk hukum Nasional. UUJN ini merupakan implementasi dari Pasal 1868

7 Kie, Than Thong. (2007). Studi Notariat, Serba Serbi Praktek Notaris, Jakarta: Ichtiar Baru
KUHPerdata yang menyebutkan bahwa, "suatu akta otentik adalah suatu akta yang dibuat dalam bentuk yang ditentukan undang-undang oleh atau di hadapan pejabat umum yang berwenang untuk itu di tempat akta itu dibuat." Pasal 1868 KUHPerdata ini telah menunjuk suatu pejabat umum untuk membentuk suatu akta otentik, dan yang dimaksud dalam pejabat umum yang berwenang ini salah satunya yaitu Notaris.

Menurut ketentuan dalam Pasal 1 ayat (1) UUJN-P disebutkan bahwa Notaris adalah pejabat umum yang berwenang untuk membuat akta otentik dan kewenangan lainnya sebagaimana dimaksud dalam undang-undang ini. Kewenangan Notaris ditentukan secara jelas dalam Pasal 15 UUJN-P, yang menentukan bahwa:

1. Notaris berwenang membuat akta otentik mengenai semua perbuatan, perjanjian, dan ketetapan yang diharuskan oleh peraturan perundang-undangan dan/atau yang dikehendaki oleh yang berkepentingan untuk dinyatakan dalam akta otentik, menjamin kepastian tanggal pembuatan akta, menyimpan akta, memberikan grosse, salinan dan kutipan akta, semuanya itu sepanjang pembuatan akta-akta itu tidak juga ditugaskan atau dikecualikan kepada pejabat lain atau orang lain yang ditetapkan oleh undang-undang.

2. Notaris berwenang pula:

a. mengesahkan tanda tangan dan menetapkan kepastian tanggal surat di bawah tangan dengan mendaftar dalam buku khusus;

b. membukukan surat-surat di bawah tangan dengan mendaftar dalam buku khusus;

c. membuat copy dari asli suratsurat di bawah tangan berupa salinan yang memuat uraian sebagaimana ditulis dan

Van Hoeve, h. 444. 
digambarkan dalam surat yang bersangkutan;

d. melakukan pengesahan kecocokan fotocopi dengan surat aslinya;

e. memberikan penyuluhan hukum sehubungan dengan pembuatan akta;

f. membuat akta yang berkaitan dengan pertanahan; atau

g. membuat akta risalah lelang.

3. Selain kewenangan sebagaimana dimaksud pada ayat (1) dan ayat (2), Notaris mempunyai kewenangan lain yang diatur dalam peraturan perundang-undangan.

Berdasarkan uraian diatas menunjukan bahwa sifat dari keotentikan suatu akta tergantung dari bentuk akta tersebut yang diatur dalam undangundang serta dibuat oleh pejabat yang berwenang di wilayah hukum kewenangannya, dalam hal ini menunjukan kewenangan utama dari Notaris adalah untuk membuat akta otentik sehingga dengan demikian akta yang dibuat oleh Notaris dalam kedudukannya tersebut memperoleh sifat akta otentik, dalam menjalankan kewenangan seorang Notaris tentu mempunyai kewajiban yang wajib dijalankannya. Kewajiban menurut Kamus Besar Bahasa Indonesia (yang selanjutnya disebut $\mathrm{KBBI}$ ), diartikan sebagai sesuatu yang diwajibkan, sesuatu yang harus dilaksanakan atau dapat diartikan juga sebagai suatu keharusan. Sehingga kewajiban notaris adalah sesuatu yang harus dilaksanakan oleh notaris dalam menjalankan jabatannya, karena sudah menjadi suatu keharusan yang diwajibkan oleh UUJN.

Sebagai jabatan dan profesi yang terhormat notaris mempunyai kewajibankewajiban yang harus dilaksanakan baik berdasarkan peraturan perundangundangan yang khusus mengatur mengenai notaris, yaitu UUJN maupun peraturan perundang-undangan lainnya yang harus ditaati oleh notaris. Kewajiban Notaris ditentukan dalam Pasal 16 UUJN$P$ yaitu:

1. Dalam menjalankan jabatannya, Notaris wajib:

a. bertindak amanah, jujur, saksama, mandiri, tidak berpihak, dan menjaga kepentingan pihak yang terkait dalam perbuatan hukum;

b. membuat Akta dalam bentuk Minuta Akta dan menyimpannya sebagai bagian dari Protokol Notaris;

c. melekatkan surat dan dokumen serta sidik jari penghadap pada Minuta Akta;

d. mengeluarkan Grosse Akta, Salinan Akta, atau Kutipan Akta berdasarkan Minuta Akta;

e. memberikan pelayanan sesuai dengan ketentuan dalam Undang-Undang ini, kecuali ada alasan untuk menolaknya;

f. merahasiakan segala sesuatu mengenai Akta yang dibuatnya dan segala keterangan yang diperoleh guna pembuatan Akta sesuai dengan sumpah/janji jabatan, kecuali undang-undang menentukan lain;

g. menjilid Akta yang dibuatnya dalam 1 (satu) bulan menjadi buku yang memuat tidak lebih dari 50 (lima puluh) Akta, dan jika jumlah Akta tidak dapat dimuat dalam satu buku, Akta tersebut dapat dijilid menjadi lebih dari satu buku, dan mencatat jumlah Minuta Akta, bulan, dan tahun pembuatannya pada sampul setiap buku;

h. membuat daftar dari Akta protes terhadap tidak dibayar atau tidak diterimanya surat berharga;

i. membuat daftar Akta yang berkenaan dengan wasiat menurut urutan waktu pembuatan Akta setiap bulan; 
j. mengirimkan daftar Akta sebagaimana dimaksud dalam huruf i atau daftar nihil yang berkenaan dengan wasiat ke pusat daftar wasiat pada kementerian yang menyelenggarakan urusan pemerintahan di bidang hukum dalam waktu 5 (lima) hari pada minggu pertama setiap bulan berikutnya;

k. mencatat dalam repertorium tanggal pengiriman daftar wasiat pada setiap akhir bulan;

1. mempunyai cap atau stempel yang memuat lambang negara Republik Indonesia dan pada ruang yang melingkarinya dituliskan nama, jabatan, dan tempat kedudukan yang bersangkutan;

m. membacakan Akta di hadapan penghadap dengan dihadiri oleh paling sedikit 2 (dua) orang saksi, atau 4 (empat) orang saksi khusus untuk pembuatan Akta wasiat di bawah tangan, dan ditandatangani pada saat itu juga oleh penghadap, saksi, dan Notaris; dan

n. menerima magang calon Notaris.

2. Kewajiban menyimpan Minuta Akta sebagaimana dimaksud pada ayat (1) huruf $\mathrm{b}$ tidak berlaku, dalam hal Notaris mengeluarkan Akta in originali.

3. Akta in originali sebagaimana dimaksud pada ayat meliputi:

a. Akta pembayaran uang sewa, bunga, dan pensiun;

b. Akta penawaran pembayaran tunai;

c. Akta protes terhadap tidak dibayarnya atau tidak diterimanya surat berharga;

d. Akta kuasa;

e. Akta keterangan kepemilikan; dan f. Akta lainnya sesuai dengan ketentuan peraturan perundangundangan.

4. Akta in originali sebagaimana dimaksud pada ayat (2) dapat dibuat lebih dari 1 (satu) rangkap, ditandatangani pada waktu, bentuk, dan isi yang sama, dengan ketentuan pada setiap Akta tertulis kata-kata "BERLAKU SEBAGAI SATU DAN SATU BERLAKU UNTUK SEMUA".

5. Akta in originali yang berisi kuasa yang belum diisi nama penerima kuasa hanya dapat dibuat dalam 1 (satu) rangkap.

6. Bentuk dan ukuran cap atau stempel sebagaimana dimaksud pada ayat (1) huruf 1 ditetapkan dengan Peraturan Menteri.

7. Pembacaan Akta sebagaimana dimaksud pada ayat (1) huruf $m$ tidak wajib dilakukan, jika penghadap menghendaki agar Akta tidak dibacakan karena penghadap telah membaca sendiri, mengetahui, dan memahami isinya, dengan ketentuan bahwa hal tersebut dinyatakan dalam penutup Akta serta pada setiap halaman Minuta Akta diparaf oleh penghadap, saksi, dan Notaris.

8. Ketentuan sebagaimana dimaksud pada ayat (7) dikecualikan terhadap pembacaan kepala Akta, komparasi, penjelasan pokok Akta secara singkat dan jelas, serta penutup Akta.

9. Jika salah satu syarat sebagaimana dimaksud pada ayat (1) huruf $m$ dan ayat (7) tidak dipenuhi, Akta yang bersangkutan hanya mempunyai kekuatan pembuktian sebagai akta di bawah tangan.

10. Ketentuan sebagaimana dimaksud pada ayat (9) tidak berlaku untuk pembuatan Akta wasiat.

11. Notaris yang melanggar ketentuan sebagaimana dimaksud pada ayat (1) 
huruf a sampai dengan huruf 1 dapat dikenai sanksi berupa:

a. peringatan tertulis;

b. pemberhentian sementara;

c. pemberhentian dengan hormat; atau

d. pemberhentian dengan tidak hormat.

12. Selain dikenai sanksi sebagaimana dimaksud pada ayat (11), pelanggaran terhadap ketentuan Pasal 16 ayat (1) huruf j dapat menjadi alasan bagi pihak yang menderita kerugian untuk menuntut penggantian biaya, ganti rugi, dan bunga kepada Notaris.

13. Notaris yang melanggar ketentuan sebagaimana dimaksud pada ayat (1) huruf $\mathrm{n}$ dapat dikenai sanksi berupa peringatan tertulis."

Dapat ditemukan dalam Pasal 16 ayat (1) huruf c bahwa notaris berkewajiban untuk melekatkan sidik jari penghadap pada minuta akta. Sidik jari (finger print) adalah hasil reproduksi tapak jari baik yang sengaja diambil, dicapkan dengan tinta maupun bekas yang ditinggalkan pada benda karena pernah tersentuh kulit telapak tangan atau kaki. Kulit telapak adalah kulit pada bagian telapak tangan mulai dari pangkal pergelangan sampai kesemua ujung jari, dan kulit bagian dari telapak kaki mulai dari tumit sampai ke ujung jari yang mana pada daerah tersebut terdapat garis halus menonjol yang keluar satu sama lain yang dipisahkan oleh celah atau alur yang membentuk struktur tertentu.

Kewajiban melakukan pelekatakan sidik jari para penghadap yang ditentukan dalam Pasal 16 ayat (1) huruf $C$ tentunya muncul banyak pertanyaan, salah satunya mengapa dilakukan kewajiban tersebut. Hal ini dilatarbelakangi dengan tujuan untuk mengantisipasi apabila suatu saat para penghadap menyangkal tandatangannya pada minuta akta, maka sebagai bukti tambahan digunakan sidik jari penghadap tersebut. Melekatkan dokumen sidik jari penghadap pada Minuta Akta memang ada manfaatnya dan merupakan sikap kehati-hatian. Namun apabila kewajiban untuk melekatkan dokumen sidik jari tersebut diwajibkan kepada penghadap yang bisa membubuhkan tanda tangannya, hendaknya kewajiban tersebut diberlakukan juga terhadap para saksi, sebab keberadaan para saksi merupakan salah satu di antara persyaratan otensitas suatu akta notaris

\section{Prosedur Pelaksanaan Terhadap Kewajiban Notaris Dalam Melekatkan Sidik Jari Para Penghadap Pada Minuta Akta.}

Diwajibkannya Notaris melekatkan sidik jari penghadap pada Minuta Akta adalah untuk memberikan kepastian hukum mengenai kebenaran identitas bagi para penghadap di dalam akta Notaris, sehingga diharapkan tidak ada penyangkalan dari masing-masing pihak terkait keadaan berhadapan dengan Notaris di dalam akta autentik. Sidik jari (fingerprint) adalah hasil reproduksi tapak jari baik yang sengaja diambil dengan tinta, maupun bekas yang ditinggalkan pada benda karena pernah tersentuh kulit telapak tangan atau kaki. Sementara bagi Notaris sendiri dengan adanya sidik jari para penghadap tersebut dapat memberikan perlindungan hukum jika dikemudian hari timbul sengketa terkait keadaan berhadapan di dalam akta Notaris, dimana sidik jari tersebut mempunyai arti penting sebagai back-up yang menyatakan bahwa Notaris telah menjalankan fungsi jabatanya sesuai dengan ketentuan peraturan perundang-undangan yang berlaku.

Terkait amanat Pasal 16 ayat (1) huruf c, dalam setiap pembuatan akta hendaknya Notaris meminta kepada penghadap untuk membubuhkan sidik jari (ibu jari/jempol) kiri yang dilekatkan pada Minuta Akta, walaupun tidak ada larangan apabila ada Notaris yang melekatkan sidik 
jari pada Minuta Akta dengan jari yang lain selain ibu jari, sebab memang tidak ada penjelasan lebih lanjut dalam UUJN mengenai sidik jari mana yang dilekatkan pada Minuta Akta. Mengenai permasalahan sidik jari penghadap diletakkan apakah dilakukan di lembar terpisah atau tidak dengan minuta akta, bahwa prosedur pembubuhan sidik jari penghadap dilakukan pada lembar tersendiri atau lembar tambahan dengan mencantumkan perbuatan hukum, nama penghadap, cap jempol, dan keterangan pada lembar tambahan tersebut. Menurutnya sidik jari penghadap tersebut dilekatkan pada lembaran kertas tersendiri, hal ini dilakukan karena lembaran yang berisi sidik jari para penghadap tersebut harus dilekatkan bersamaan dengan dijahitnya Minuta Akta, dan pada bagian akhir penutup akta mengenai telah ditandatangani dan dibubuhi sidik jari penghadap dengan keterangan sebagai berikut: "Setelah akta ini dibacakan oleh saya, Notaris kepada para penghadap, dan para saksi, maka pada ketika itu juga para penghadap membubuhkan tanda tangannya juga membubuhkan sidik jari tangan kiri pada lembaran kertas tersendiri yang dilekatkan pada minuta akta ini, para saksi, dan saya, Notaris menandatanganinya."

Menjalankan kewajiban melekatkan sidik jari tersebut dalam pelaksanaannya terdapat beberapa hambatan-hambatan dalam pembubuhan sidik jari para penghadap pada minuta akta. Terkadang Notaris menjumpai penghadap yang tidak mau membubuhkan sidik jarinya pada lembar kertas tersendiri yang telah disediakan oleh Notaris untuk keperluan tersebut dengan alasan sudah membubuhkan tanda tangannya. Hal ini menjadi kendala bagi Notaris manakala penghadap tersebut tidak mau membubuhkan sidik jarinya. Untuk menghadapi persoalan tersebut Notaris harus memberikan penyuluhan hukum terkait pentingnya sidik jari pada Minuta Akta. Pasal 15 ayat (2) huruf e UUJN menyebutkan "Notaris berwenang pula memberikan penyuluhan hukum sehubungan dengan pembuatan akta”.

\section{Akibat Hukum Terhadap \\ Kedudukan Akta Dan Notaris Yang Tidak Melakukan Pembubuhan Sidik Jari Tangan Para Penghadap Pada Minuta Akta Berdasarkan UUJN-P.}

Sebelum membahas akibat hukum terhadap kedudukan akta notaris yang tidak melakukan pembubuhan sidik jari para penghadap pada minuta akta, perlu dipahami akta notaris sebagai alat bukti umumnya. Maka akta notaris dibedakan menjadi tiga macam kekuatan pembuktian yakni

1. Kekuatan pembuktian lahiriah (uitwendige bewijskracht) yang merupakan kekuatan pembuktian dalam artian kemampuan dari akta itu sendiri untuk membuktikan dirinya sebagai akta otentik. Kemampuan ini berdasarkan Pasal 1875 Kitab Undang-Undang Hukum Perdata tidak dapat diberikan kepada akta yang dibuat di bawah tangan. Akta yang dibuat di bawah tangan baru berlaku sah, yakni sebagai yang benar-benar berasal dari pihak, terhadap siapa akta tersebut dipergunakan, apabila yang menandatanganinya mengakui kebenaran dari tanda tangannya itu atau dengan cara yang sah menurut hukum telah diakui oleh yang bersangkutan. Sementara akta otentik membuktikan sendiri keabsahannya. Suatu akta nampak sebagai akta otentik, artinya menandakan dirinya dari luar, dari kata-katanya sebagai seorang pejabat umum, maka akta itu terhadap setiap orang dianggap akta otentik sampai dapat dibuktikan bahwa akta tersebut bukanlah akta otentik. 
2. Kekuatan pembuktian formal (formale bewijskracht) Merupakan kepastian bahwa suatu kejadian dan fakta tersebut dalam akta betul-betul dilakukan oleh notaris atau diterangkan oleh pihak-pihak yang menghadap. Artinya bahwa pejabat yang bersangkutan telah menyatakan dalam tulisan sebagaimana yang tercantum dalam akta itu dan selain dari itu kebenaran dari apa yang diuraikan oleh pejabat dalam akta itu sebagai yang dilakukan dan disaksikannya di dalam jabatan itu. Dalam arti formal, sepanjang mengenai akta pejabat, akta itu membuktikan kebenaran dari apa yang disaksikan, yakni yang dilihat, didengar, dan juga dilakukan sendiri oleh notaris sebagai pejabat umum di dalam menjalankan jabatannya. Pada akta dibawah tangan kekuatan pembuktian ini hanya meliputi kenyataan bahwa keterangan itu diberikan, apabila tanda tangan yang tercantum dalam akta dibawah tangan itu diakui oleh yang yang menandatanganinya atau dianggap telah diakui sedemikian menurut hukum. Dalam arti formal, maka terjamin kebenaran/kepastian tanggal dari akta otentik, kebenaran tandatangan, identitas dari orangorang yang hadir, demikian juga tempat akta dibuat. Pada akta otentik berlaku terhadap setiap orang yakni apa yang ada dan terdapat diatas tandatangan mereka. Namun terdapat kekecualian atau pengingkaran atas kekuatan pembuktian formal ini. Pertama, pihak penyangkal dapat langsung tidak mengakui bahwa tanda tangan yang dibubuhkan dalam akta tersebut adalah tanda tangannya. Kedua, pihak penyangkal dapat menyatakan bahwa notaris dalam membuat akta melakukan suatu kesalahan atau kekhilafan namun tidak menyangkal tanda tangan yang ada di dalam akta tersebut. Artinya pihak penyangkal tidak mempersoalkan formalitas akta namun mempersoalkan substansi akta. Dalam membuktikan hal ini menurut hukum dapat digunakan segala hal yang berda dalam koridor hukum formil pembuktian

3. Kekuatan pembuktian material (materiele bewijskracht) Merupakan kepastian bahwa apa yang tersebut dalam akta itu merupakan pembuktian yang sah terhadap pihak-pihak yang membuat akta atau mereka yang mendapat hak dan berlaku untuk umum, kecuali ada pembuktian sebaliknya. Artinya tidak hanya kenyataan yang dibuktikan oleh suatu akta otentik, namun isi dari akta itu dianggap dibuktikan sebagai yang benar terhadap setiap orang, yang menyuruh membuatkan akta itu sebagai tanda bukti terhadap dirinya. Akta otentik dengan demikian mengenai isi yang dimuatnya berlaku sebagai yang benar, memiliki kepastian sebagai sebenarnya maka menjadi terbukti dengan sah diantara para pihak oleh karenanya apabila digunakan di muka pengadilan adalah cukup dan bahwa hakim tidak diperkenankan untuk meminta tanda pembuktian lainnya disamping akta otentilk tersebut. Hakim terikat dengan alat bukti otentik sebab jika tidak demikian maka dapat dipertanyakan apa gunanya undang-undang menunjuk para pejabat yang ditugaskan untuk membuat suatu akta otentik sebagai alat bukti bila hakim dapat begitu saja mengesampingkan akta yang dibuat oleh pejabat tersebut.

Akta notaris merupakan perjanjian para pihak yang mengikat mereka yang membuatnya, oleh karena itu syarat-syarat sahnya perjanjian harus dipenuhi. Pasal 1320 Kitab Undang-Undang Hukum 
Perdata yang mengatur tentang syarat sahnya perjanjian, ada syarat subyektif yaitu syarat yang berkaitan dengan subjek yang mengadakan atau membuat perjanjian, yang terdiri dari kata sepakat dan cakap bertindak untuk melakukan suatu perbuatan hukum, dan syarat obyektif yaitu syarat yang berkaitan dengan perjanjian itu sendiri atau berkaitan dengan objek yang dijadikan perbuatan hukum oleh para pihak, yang terdiri dari suatu hal tertentu dan sebab yang tidak dilarang. ${ }^{8}$

Seorang notaris dalam membuat suatu akta berpedoman pada syarat sahnya perjanjian yang ditentukan dalam Pasal 1320 KUHPerdata. Kaitannya dengan pembubuhan sidik jari bahwa dalam UUJN tidak ada satu pasal yang menyebutkan akta Notaris yang tidak dilekatkan sidik jari dapat terdegradasi ataupun menurunkan sifat akta Notaris menjadi akta di bawah tangan, hal ini sebagaimana ditegaskan dalam Pasal 16 ayat (11) UUJN, bahwa Notaris yang tidak melaksanakan tugasnya untuk melekatkan sidik jari penghadap pada Minuta Akta hanya dapat dikenakan sanksi berupa peringatan tertulis, tanpa mengurangi status ataupun sifat dari akta yang dibuat oleh Notaris yang bersangkutan, jadi mengenai hal ini Notaris hanya diberi peringatan tertulis dan aktanya tetap sah dan mengikat serta mempunyai kekuatan pembuktian yang sempurna. Agar akta itu menjadi akta autentik dan tetap sah maka Notaris dalam pembuatan aktanya harus memenuhi syarat-syarat yang dinyatakan dalam Pasal 1868 dan Pasal 1320 KUHPerdata, namun Notaris juga tetap menjalankan kewajiban Pasal 16 ayat (1) huruf c UUJN-P.

Notaris yang tidak melaksanakan ketentuan Pasal 16 ayat (1) huruf c maka Notaris tersebut dapat dikenai sanksi administratif, menurutnya yang

8 Adjie, Habib. (2009). Sekilas Dunia Notaris dan PPAT Indonesia, Bandung: Mandar Maju, h. 37.

9 Habib Adjie. (2011). Hukum Notaris berwenang menjatuhkan sanksi adalah Majelis Pengawas Wilayah (MPW), sedangkan Majelis Pengawas Daerah hanya melakukan pemeriksaan dan pembinaan secara langsung dan rutin kepada Notaris, dan jika dalam pemeriksaan ditemukan adanya pelanggaran, maka Majelis Pengawas Daerah (MPD) hanya mengusulkan kepada Majelis Pengawas Wilayah. Menurut Habib Adjie, ${ }^{9}$ secara garis besar sanksi administratif dapat dibedakan 3 (tiga) macam, yaitu: Sanksi Reparatif, Sanksi Punitif dan Sanksi Regresif. Pembubuhan sidik jari penghadap merupakan bagian dari kewajiban Notaris untuk melekatkannya dalam Minuta Akta, meskipun apabila terjadi pelanggaran terhadap kewajiban melekatkan sidik jari penghadap, tidak dapat menyebabkan akta yang dibuat oleh Notaris menjadi terdegradasi menjadi pembuktian akta di bawah tangan, namun demikian Notaris yang melanggar tersebut dapat dijatuhi atau dikenai sanksi administratif.

\section{P E N U T U P}

Berdasarkan uraian-uraian yang telah dikemukakan, maka penulis dapat menarik kesimpulan yaitu kewajiban notaris untuk melekatkan sidik jari penghadap di latar belakangi dengan tujuan untuk mengantisipasi apabila suatu saat para penghadap menyangkal tandatangannya pada Minuta Akta, maka sebagai bukti tambahan digunakan sidik jari penghadap tersebut. Melekatkan dokumen sidik jari penghadap pada Minuta Akta memang ada manfaatnya dan merupakan sikap kehati-hatian. Selain itu mengenai prosedur pelaksanaannya bahwa mengenai kewajiban notaris melekatkan sidik jari menggunakan cap jempol/ibu jari kiri. Sidik jari penghadap tersebut dibuatkan di satu lembar baru

Indonesia, Tafsir Tematik Terhadap UU No. 30 Tahun 2004 Tentang Jabatan Notaris. Cetakan Ketiga. Bandung: Refika Aditama, h. 221. 
atau lebar tambahan. Dalam pelaksanaannya terkadang menemui kendala misalnya penghadap tidak mau melakukan pembubuhan sidik jarinya karena penghadap merasa sudah membubuhkan tanda tangan, atas kendala tersebut Notaris memberikan penyuluhan hukum terkait pembubuhan sidik jari. Dan terhadap Notaris yang tidak melaksanakan kewajiban melekatkan sidik jari para penghadap pada Minuta Akta tidak mengurangi keabsahan atau otentisitas dari akta yang dibuat oleh Notaris yang bersangkutan. Jadi secara normatif tidak melekatkan sidik jari tersebut tidak memberi pengaruh terhadap kedudukan aktanya, akta Notaris tetap sah dan mengikat serta mempunyai kekuatan pembuktian yang sempurna. Terhadap Notaris yang tidak melaksanakan kewajiban melekatkan sidik jari penghadap pada Minuta Akta sebagaimana diamanatkan dalam Pasal 16 ayat (1) huruf c, maka terhadap pelanggaran tersebut Notaris dapat terkena sanksi administratif sebagaimana diatur dalam Pasal 16 ayat (11) UUJN.

\section{DAFTAR PUSTAKA}

Adjie, Habib. (2009). Sekilas Dunia Notaris dan PPAT Indonesia, Bandung: Mandar Maju. (2011). Hukum Notaris Indonesia, Tafsir Tematik Terhadap UU No. 30 Tahun 2004 Tentang Jabatan Notaris. Cetakan Ketiga. Bandung: Refika Aditama.

Marzuki, P.M. (2013). Penelitian Hukum. Jakarta: Kencana Prenada Media Group.

Soekanto, S. \& Mamudji. S. (2009). Penelitian Hukum Normatif Suatu Tinjauan Singkat. Jakarta: PT RajaGrafindo Persada.

Supriadi. (2006). Etika dan Tanggung Jawab Profesi Hukum di Indonesia. Jakarta: Sinar Grafika.
Than Thong Kie. (2007). Studi Notariat, Serba Serbi Praktek Notaris, Jakarta: PT Ichtiar Baru Van Hoeve

\section{Peraturan Perundang-Undangan}

Kitab Undang-Undang Hukum Perdata Terjemahan R. Subekti dan R. Tjitrosudibio.

Undang-Undang Nomor 30 Tahun 2004 (Lembaran Negara Republik Indonesia Tahun 2004 Nomor 117, Tambahan Lembaran Negara Republik Indonesia Nomor 4432).

Undang-Undang Nomor 2 Tahun 2014 Tentang Perubahan Atas UndangUndang Nomor 3 Tahun 2004 Tentang Jabatan Notaris (Lembaran Negara Republik Indonesia Tahun 2014 Nomor 3, Tambahan Lembaran Negara Republik Indonesia Nomor 5491)

\section{Lain - Lain}

Dinaryanti, A. R. (2013). Tinjauan Yuridis Legalisasi Akta Di Bawah Tangan Oleh Notaris. Legal Opinion, 1 (3).

Sajadi, I., Saptanti, N., \& Supanto, S. (2015). Tanggung Jawab Notaris Terhadap Keabsahan Akta Notaris Yang Dibuatnya Atas Penghadap Yang Tidak Dapat Membaca dan Menulis. Repertorium, 2 (2).

Sukisno, D. (2008). Pengambilan Foto Copi Minuta Akta dan Pemanggilan Notaris. Mimbar Hukum-Fakultas Hukum Universitas Gadjah Mada, 20 (1). 